\title{
SCIENTIFIC RESEARCH
}

\section{INWARD POLITICAL PROCESSES AND FOREIGN POLICY}

\author{
DOI: 10.54631/VS.2021.S-11-22 \\ PRE-UNIFICATION TRANSITION IN SOUTH VIETNAM AND THE HO \\ CHI MINH CITY MILITARY ADMINISTRATION (1975-1976)
}

\author{
Antoine Lê
}

\begin{abstract}
Using materials from the Vietnam's National Archives Center No. 2, in particular the incomplete series of the Military Administration Committee's weekly or monthly reports, as well as recently published archival documents from the Central Office of South Vietnam (COSVN), this paper aims to shed light on the issue of "Tiếp quản", the transition of power in Saigon after 30 April 1975 from the Republic of Vietnam (RVN) to the combined Vietnamese revolutionary forces by studying the Üy ban Quân quản Thành phố Sài Gòn - Gia định (UBQQSG), the Military Administration Committee for the City of Saigon - Gia Dinh.

This paper will start by examining what kind of challenge Saigon represented for the Vietnamese revolution and how the revolutionaries prepared to face it. Second it will tackle the issue of the presence of Southerners in the state apparatus for transition. Third, it will go over the main policies that the UBQQSG implemented, what resistance it confronted and how it struggled with issues of discipline amongst its assigned cadres. Finally, the article proposes an expansion of the dates in which the Vietnam War is generally examined by pushing back the end of the periodization to July 1976 and the official reunification of Vietnam.

Keywords: 1975, Saigon, Military Administration Committee, transition, Republic of South Vietnam, Ho Chi Minh City.

For citation: Lê Antoine (2021). Pre-Unification Transition in South Vietnam and the Ho Chi Minh City Military Administration (1975-1976). Russian Journal of Vietnamese Studies, Special issue: 11-22.
\end{abstract}

\section{Introduction}

When the People's Army of Vietnam (PAVN) tanks broke open the gates of the Saigon Presidential Palace on 30 April 1975, they were carrying flags of the National Liberation Front for South Vietnam (NLF) /Provisional Revolutionary Government of the Republic of South Vietnam (PRG). The belief that the South Vietnamese liberation movement was freeing its own country was to be upheld until the very end. However, in the hour when these Southern organizations were supposed to assume the responsibilities that they were created for, another form of government took over the state apparatus: the military administration committees. This paper examines the following questions: What was the place and the role of the Southern revolutionaries in the taking over of the 
city of Saigon - Gia Dinh? Was the city's military administration the last breath of the revolution promised in South Vietnam by the NLF/PRG in the 1960s or the first step towards the South's forceful integration under Hanoi's rule?

The conditions of the military administration were defined in the beginning of April 1975 by the political headquarters of the Party in the South: The Central Office for South Vietnam (COSVN). They aimed to rely on the deployment of the military forces of the PAVN from the North and the Southern People's Liberation Armed Forces (PLAF) in every locality of South Vietnam to build new revolutionary administrations. The city of Saigon - Gia Dinh, capital of the Republic of Vietnam (RVN), was to be no exception and its Military Administration Committee (Ủy ban Quân quản thành phố Sài Gòn - Gia Định, UBQQSG), was made to be one of the highest authorities of the overall process of transition (Tiếp quản) in South Vietnam.

Created on 3 May 1975 following a COSVN directive from 10 April, officially led by General Tran Van Tra (Trần Văn Trà), and composed of other COSVN leadership members such as Vo Van Kiet (Võ Văn Kiệt), Mai Chi Tho (Mai Chí Thọ), Tran Van Danh (Trần Văn Danh), Cao Đang Chiem (Cao Đăng Chiếm), the UBQQSG's mission was to take over the city of Saigon and ensure the transition from the defeated RVN regime to the new revolutionary power officially represented in the South by the Provisional Revolutionary Government of the Republic of South Vietnam (PRG).

Recent research on the Vietnamese revolutionary side of the Vietnam War has mainly focused on the leaders of the Democratic Republic of Vietnam (DRV) [Lien-Hang 2012; Asselin 2018]. In particular, the war's closing moments in 1975, and the takin-g of Saigon, have been the object of very little scholarship concerning the South Vietnamese revolutionaries. 30 April 1975 indeed serves as a key date, representing a conclusion for most of the historical works published both inside and outside of Vietnam concerning the thirty-year conflict. The implicit subtext being that through this final military victory, Hanoi was able to secure its power over the whole country and impose its own vision of a long-awaited reunification. This narrative of a Northern takeover of the South by force was reinforced in the years following the war by the accounts of former Southern Vietnamese revolutionaries and sympathizers of the NLF or the Provisional Revolutionary Government for the Republic of South-Vietnam (PRG) in exile [Trương Như Tảng 1986]. A few recent publications in France and in the United States have started to outline the main issues of analyzing the immediate post-war period through the lens of a complete Northern takeover of South [Goscha 2016; Guillemot 2018]. This view that has been further discussed by journalist Huy Đuc's study of the "liberation" published in Vietnamese in 2012 [Huy Đức 2012]. While there is no denying that Northern presence in the South was greatly augmented in all aspects of the administration and state apparatus after 1975, recent findings in the Vietnam's National Archives lead to more nuanced conclusions as to the realities of the transition period up to the beginning of 1976.

\section{Saigon as the Gordian knot of the Vietnamese revolution}

It is worth remembering that the city of Saigon had long been a thorn in the side of Vietnamese revolutionaries. Already during the foundational moments of the summer of 1945, the path to the Viet Minh hegemony over the city had been a complicated one. The Vietnamese revolutionaries, even if they lost control of the Southern capital, never ceased to consider it a major objective of their war effort and always maintained at least a clandestine presence in the city. The fact remains that to the communist-inspired Viet Minh and its successors, Saigon was the embodiment of the Western, feudalist and capitalist corruption, the epicenter of counter-revolution. Yet, the Southern capital had only known major combat on two instances since the 1950s, in 1955 and during the Tet Offensive of 
1968. But unlike Viet Minh commander Nguyen Binh who argued in 1947 that "Destroying Saigon is a very legitimate and humane action" [Goscha 2011: 159], the taking over of Saigon in 1975 was to dispel the specter of 1968 or more generally the fear of a massive Communist repression. The revolutionaries knew that the whole world would be looking on their first steps after the final victory. Saigon was to be the example, the showcase of the Communist-led revolution to come, and of the peace and ultimate reunification of the country. Keeping up appearances, all the while establishing a strict control over information media both foreign and domestic, was key to the whole operation's success.

\section{Planning for the taking over of the city: COSVN directive No.06/CT75}

The COSVN had already elaborated its own solution for taking over the city: establishing a military administration. On 10 April 1975, the COSVN released its directive no.06/CT75, "on the preparation of the transition process in Saigon - Gia Dinh city" [COSVN Documents, Vol. 18, 2020: 835]. This document was itself one in a series of documents that circulated from the COSVN to the cadres at every level of the revolutionary government and the army to specify the instructions, behaviors and objectives that they had to adopt in the "newly liberated areas" in the first weeks of April 1975. Directive 06/CT.75 argued for a temporary military administration based on the deployment of revolutionary troops inside the city in order to stabilize the situation and secure the transition for a new revolutionary government. It also specified the four missions of the UBQQSG:

1. "To continue to destroy pockets of resistance, to hunt down and completely eliminate the enemy, especially its armed forces and reactionary organizations.

2. To quickly stabilize the situation and establish order and peace in the city; to build an armed self-defense force of the masses in every street, in the factories, and to use the revolutionary mass organizations as a backbone.

3. To gradually restore the infrastructure necessary for people's lives, such as: food supply, transportation and employment.

4. Prepare the conditions for transition to a revolutionary government" [Ibid].

The order in which those missions are stipulated shows that on 10 April, the COSVN was still unsure about what to expect when taking Saigon, and probably considered the possibility of a prolonged urban battle like the one that revolutionary forces faced in Hue during the 1968 Tet Offensive. Only this time, they would be the ones who would have to conquer the city from an entrenched force. On the civilian and political side, the UBQQSG was to work in coordination with the Party Committee of the City (Thành ủy), itself tasked with mobilizing the masses around the new regime (Fig. 1). Both organizations were put under the leadership of the COSVN, with COSVN members at the leadership of them. The UBQQSG was also to establish various departments (propaganda, security, civilian mobilization, military mobilization, etc.) as well as other military administration committees at all the echelons of the new state apparatus in 14 urban and 7 rural districts that made up the city then. Military administrations were to be set up at the district, ward, and neighborhood levels [Hồ Sơn Đài 2015]. For this endeavor the UBQQSG was to receive reinforcement from the COSVN who, along with the DRV, would send in 2,820 low- and mid-level cadres of its various committees and ministries to form sub-committees in charge of implementing the transition in their specific domain of activities [Nguyễn Đình Thống 2019:191]. All of these revolutionary agents were cautioned against the "ruses of the reactionaries, and the material luxury temptations that the city offered" [Directive 06/CT.75: 794-795] or phrased in Phan Van Dong's more poetic way: "poison pills encased in sugar" [Trương Như Tảng 1986: 259]. "Revolutionary and 
working-class morals" as "the victors" strict discipline" were to be strictly upheld by those cadres because of their "high responsibility towards the masses".

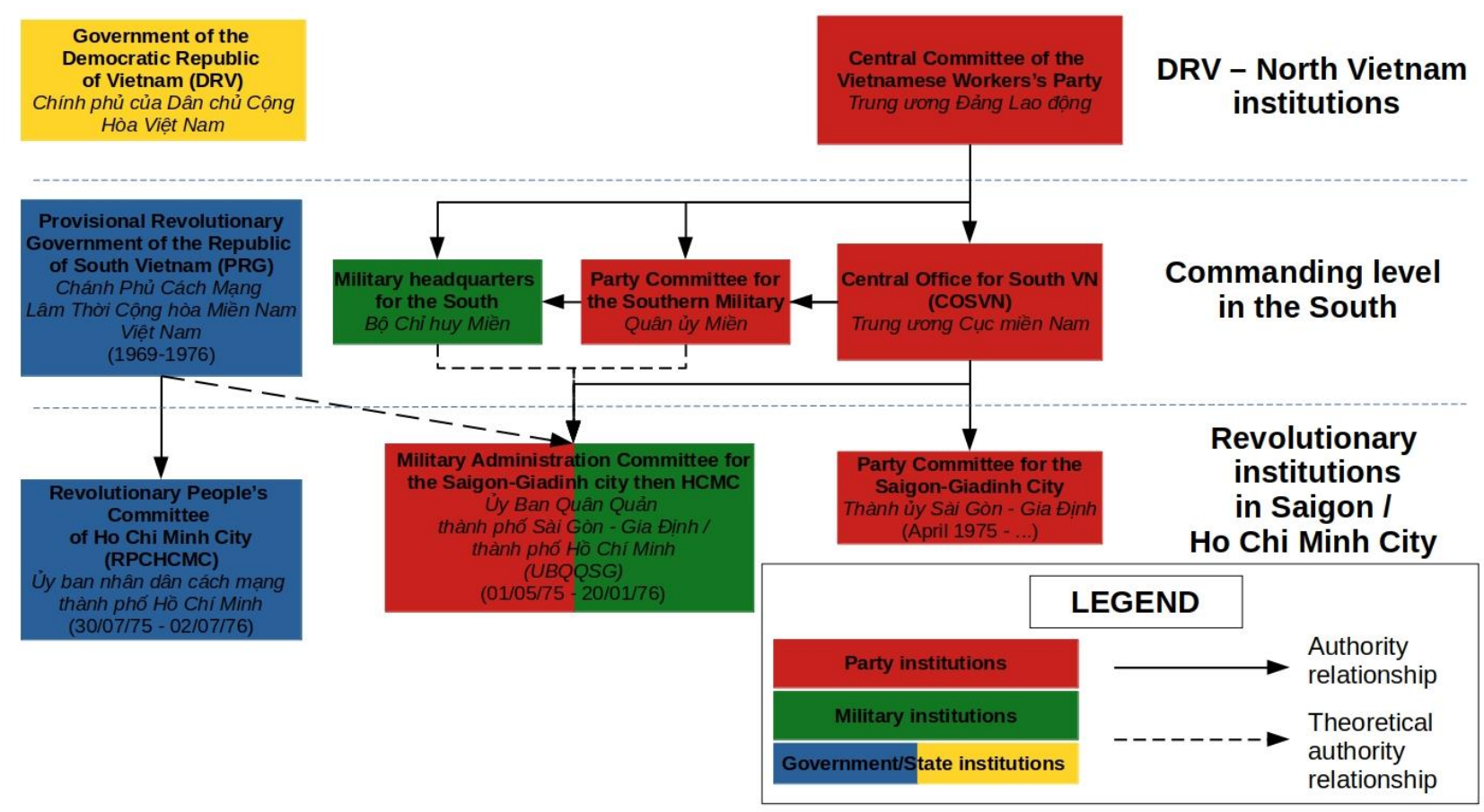

Fig. 1. Organization chart of the revolutionary institutions in South Vietnam in 1975. Picture by the author

\section{Establishing the new regime among the population and building the administrative network for the city}

These 2,820 cadres, however, were nowhere near enough to take over the city. As with the rest of the country, revolutionary authorities in Saigon had to deal with personnel shortages. The COSVN leadership pointed to a solution with directive No.08/CT75 ordering a massive training program for backbone activist supporters (cốt cán) meant to act as power relays between the cadres and the masses. According to the COSVN directive, these training sessions had priority over other missions. They were supposed to last three to five days and were aimed at promoting revolutionary achievements and revolutionary morals (such as, devotion to the people and to the Party, exemplarity of the revolutionary agents towards the masses, strict discipline in service of the people, determination to eradicate the enemy, etc.). Moreover, they were to hammer the fundamental principle of the new regime into the minds of these new supporters: "the people are sovereign in the new regime, but it is the worker-peasant class, which represents the majority, that embodies that sovereignty. The government must be that of the working class, under the leadership of the working-class Party" [COSVN Documents, Vol. 18, 2020: 835]. The Party was to be the center of everything, neither the PRG nor the NLF are mentioned in this principle. In a few weeks, these cadres and their hardcore supporters conducted thousands of study sessions, hundreds of propaganda meetings for the masses, public accusation sessions against the perceived enemies of the revolution and war criminals, etc. [UBQQSG Report, 30/04/75-20/07/75]. In short, they recreated a campaign somewhat similar in its means and its objectives to the land reform campaign undertaken in the North from 1953 to 1956. This recruitment effort was so successful that it led to the explosion of the state apparatus' workforce and structure. The first UBQQSG report from the end of July 1975 states that a total of 1,278 committees had been set up in the city and its surroundings (342 in the rural districts and 936 in the urban ones of which 828 were considered to be secure and stable while 108 had still to be put to the test) along with 3,505 backbone supporters groups spread across the districts. Yet this was only the 
beginning, because a few months later in October and November of 1975, the whole administration of the city employed 45,069 people [UBQQSG Report, 14/11-20/11/75]. According to the UBQQSG, this massive contingent of administrative workers went on to represent $50 \%$ of all the public servants in the city [UBQQSG Report, 10/10-17/10/75]. Of course, raising the numbers of servants in the state apparatus was not correlated to raising the quality of those state workers, and the UBQQSG continuously reported cases of lack of discipline, authoritarianism, lack of uniformity that led not only to unequal local implementation of policies decided at the central level but also complaints from the masses and perhaps even worse, enemy infiltration inside the state apparatus.

\section{A Southern leadership at the helm of the transition}

In the months following 30 April, some Southern revolutionaries were feeling marginalized in the PRG and the NLF according to the former PRG Minister for Justice, Truong Nhu Tang (Truong Nhu Tảng). For him, the UBQQSG had become the de facto government of South Vietnam, taking its orders directly from Hanoi while cadres from the North were slowly filling every position of power in the new government [Trương Như Tảng 1986: 265]. But if that might have been the case for the non-communist members of the resistance, Southerners were still mostly put in leadership positions in most of the governing committees. At the top level itself, of the 11 members that were chosen to lead the UBQQSG, Southerners were the majority [Nhân Dân: 04/05/1975]. General Tran Van Tra from COSVN was named President of the UBQQSG while Vo Van Kiet and Mai Chi Tho, probably representing Thành ủy, were named Vice-Presidents along with generals Hoang Cam (Hoàng Cầm) (Commander of Army Group No.4), Tran Van Danh (Military Commander for the Defense of the City) and Cao Dang Chiem, a high-ranking officer in the security and intelligence force. Five additional commissioners (ủy viên) were also assigned to the UBQQSG: Colonel Bui Thanh Khiet (Bùi Thanh Khiết) in charge of civilian affairs; Doctor Nguyen Van Thu (Nguyến Văn Thủ) for Health; Duong Ky Hiep (Duoong Ky Hiẹp), Minister of the Economy and Finances of the PRG, and sole representative of the official government of the Republic of South Vietnam; as well Nguyen Vo Danh (Nguyễn Võ Danh) and Phan Minh Tanh (Phan Minh Tánh). Of all of these UBQQSG leaders, only Mai Chi Thọ and Hoang Cam were originally from the North.

Not all were military men, revealing that Party membership was more important than military affiliation in the military administration. Indeed, all the UBQQSG leaders were long-time Party members who had either joined the revolution before 1945 or in the early stages of the resistance against the French. They were all men, between 46 and 64 years old with an average of 54 years old and had decades of experience in South Vietnam. Three of them, Vo Van Kiet, Mai Chi Tho, and Nguyen Van Thu, had led revolutionary forces in Saigon with the first two leading the Party's forces in the city during most of the war. Hanoi certainly assumed that these were people that the Central Committee could count on. After all their years of trial, they were now chosen to face a new challenge, one very different from that which they had been confronted with while still a guerrilla force: embodying the Southern liberation and building the next step of the Vietnamese revolution. And from Vo Van Kiet's own admittance: "None of those who took over Saigon in 1975 had any knowledge of state management” [Huy Đức 2012: 42].

\section{Northern invasion or southern transition: the military administration's personnel}

Contrary to a common perception, it seems Northerners were not assuming control of the whole transition apparatus in 1975. Former Viet Minh cadres from the South, who were long-time Party members in their 40s were put in charge of at least two of the main transition committees. Both the Transition Committee for Industrial Affairs (TCIA) and the Transition Committee for Agricultural 
Affairs (TCAA) were headed exclusively by Southerners who had, for the most part, entered the Party in the 1940s. As the lists of cadres composing these committees were drawn up by the COSVN in April 1975, Southerners were the majority in the TCAA, while the TCIA was mostly made up of Northerners. One explanation for this could be that the North had trained more industry specialists in the socialist ways, while competent staff in industrial matters would have likely been more affiliated with the RVN in the South. However, one fact emerges clearly from a study of the composition of these two committees: the Southern cadres sent to implement the transition in Saigon - Gia Dinh tended to be older than their Northern counterparts and they also had a higher rate of integration in the Party (see Tables 2, 3). Northerners were more likely to be members of the Youth group (Đoàn Thanh niên), the necessary step before being granted membership in the Party. Both lists of cadres sent to oversee the transition show that positions of responsibility were all assigned to Southerners and that there were few or no women amongst these contingents. From this sample, it seems that, at least at the COSVN level, the strategy was to entrust the transition process to middle aged, experienced cadres from the South with young technicians or experts from the North under their command. However, this factual situation may have changed over the months after 30 April, since reports of the UBQQ account for the integration of cadres from the Army [UBQQSG Report, 31/0504/06/75] (which was mostly composed by Northerners at the time) into the administration but also from the côt cán (who were likely to be Saigonese who had rallied to the revolutionary cause). However, having Southerners in charge did not necessarily mean that the transition administration would act in a lenient or understanding manner towards the former enemy capital city. Indeed, being born in South did not necessarily mean that cadres in charge of Saigon may have had their loyalties going to their Southern compatriots rather than to the DRV authorities who trained them. Framing it as the "The old debate between "red cadres" and "competent cadres"', Jean and Simonne Lacouture expressed doubts as soon as 1976 about the capacities of the revolutionary war leaders trained in Marxism-Leninism to take over the management of Saigon in an efficient way [Lacouture 1976]. If, in addition, one considers, like David Elliot, that "it was often the most idealistic of the revolutionaries who were the [first] victims of the war", the conclusion one logically reaches is that: "Those who survived and held on to the end were often the toughest, most doctrinaire, and unrelenting revolutionary true believers. [...] These were not always, however, the people most qualified to lead Vietnam on to the next stage of its development" [Elliott 2016: 439].

In that sense, it is possible that the Southerners in charge of the transition were also hardcore revolutionaries who felt that they finally had the occasion to punish the city that had defied them for decades. This may also have combined with a sense of self-legitimacy, due to their long careers in the Party, that to some extent freed them from their superiors' directives and allowed them to follow their own agendas.

\section{Maintaining order in the city: the UBQQSG against rampant resistance}

The UBQQSG had a part in the two main policies that were implemented in South Vietnam: first, the reeducation program for former members of the Army of the Republic of Vietnam (ARVN) and civil administration that processed 443,360 individuals in Saigon alone by April 1976 [Hà Minh Hồng 2019:151]. Second, the semi-forced, semi-encouraged displacement of at least 239,796 people from the newly renamed Ho Chi Minh City to the countryside within either the framework of the return policy (hồi hương) or the creation of so-called "New Economic Zones" (vùng kinh tế mới) [UBQQSG Report, December 1975]. Contrasting with the image of a blind repression that these policies are often represented with, the UBQQSG showed what seemed to be genuine empathy and concern for the 
difficult living conditions of these policies' subjects. In November 1975, the UBQQSG proposed establishing a support group. Their task was to collect medical supplies and clothing in the city and send to the new economic areas in order to improve the disastrous health conditions there [UBQQSG Report, 07/11-14/11/75]. In the same fashion, the UBQQSG insisted on including exceptions, to the categorizations of subjects to be reeducated, while insisting that these programs would not last longer than necessary and they aimed only to give a new start to the former RVN agents.

Table 2. Geographical origins and Party memberships of the cadres assigned to the industrial affairs transition committee in Saigon - Gia Dinh

\begin{tabular}{|c|c|c|c|c|c|c|}
\hline & North & $\begin{array}{l}\text { North- } \\
\text { Central }\end{array}$ & $\begin{array}{l}\text { South- } \\
\text { Central }\end{array}$ & South & Unknown & Total \\
\hline Numbers & 96 & 33 & 6 & 64 & 18 & 217 \\
\hline Percentage & $44 \%$ & $15 \%$ & $3 \%$ & $29 \%$ & $8 \%$ & $100 \%$ \\
\hline Party Members & 11 & 2 & 5 & 43 & 2 & 63 \\
\hline Percentage & $11 \%$ & $6 \%$ & $83 \%$ & $67 \%$ & $11 \%$ & $29 \%$ \\
\hline $\begin{array}{l}\text { Youth group } \\
\text { (Đoàn) members }\end{array}$ & 59 & 16 & & 3 & 1 & 76 \\
\hline Percentage & $58 \%$ & $48 \%$ & $0 \%$ & $5 \%$ & $6 \%$ & $35 \%$ \\
\hline Non-affiliated & 29 & 15 & 1 & 18 & 15 & 78 \\
\hline Percentage & $30 \%$ & $45 \%$ & $17 \%$ & $28 \%$ & $83 \%$ & $36 \%$ \\
\hline Average age & 27 & 26 & 44 & 43 & & 33 \\
\hline $\begin{array}{l}\text { Average age of } \\
\text { Party members }\end{array}$ & 36 & 35 & 45 & 46 & & 43 \\
\hline $\begin{array}{l}\text { Average age for } \\
\text { Đoàn members }\end{array}$ & 25 & 26 & & 31 & & 25 \\
\hline
\end{tabular}

North is the area above Thanh hóa province; North-Central covers the area from Thanh hóa province to the $17^{\text {th }}$ parallel; South-Central zone from the $17^{\text {th }}$ parallel to the present provinces of Đắk Nông, Lâm Đồng and Bình Thuận; South is the south area.

Source: Compiled from BS-109, Danh sách cán bộ lãnh đạo tiểu ban tiếp quản công nghiệp + Danh sách cán bộ công nhân đi tiếp quản in HS 73: Tài liệu của Bộ Kinh tế Tài chính, Ủy ban Quân Quản TP. HCM về công tác tiếp quản năm 1975-1976 [List of cadres and leaders of the industrial takeover subcommittee + List of staff and workers taking over in HS 73: Documents of the Ministry of Economy and Finance, Ho Chi Minh City Military Administration Committee on the takeover in 1975-1976], TTLTQGII

This concern for de-escalating conflicts with the population was also visible in the way in which the UBQQSG managed opposition to the new revolutionary government, at least in the beginning. An armed protest, organized by Catholics, that took place on the night of 3 June 1975 is illustrative of this attitude. While the protesters chanted "Down with the PRG, the revolution is not freedom!" and wounded a revolutionary agent, the authorities preferred dialogue and persuasion over brutal repression, arresting only 19 people of the 400 protesters. Yet, maintaining order in the city was still the first priority on the UBQQSG's agenda and for that purpose thousands of soldiers were deployed in the city at every level from the beginning. Catholics, ethnic Chinese (Hoa) inhabitants of Saigon were the targets of a special kind of surveillance. This did not prevent enemies of the new revolutionary regime to engage in violent resistance. As early as the beginning of August, and all through the rest of the year, the UBQQSG deplored numerous grenade attacks on the new People's 
Committees and revolutionary agents all throughout the city, killing dozens of people [UBQQSG Report, 04/08-07/08/75]. This opposition to the revolutionary authorities grew stronger with the preparations for the general elections and the official reunification of the country. Northern cadres, or those who had close ties to them were assaulted in the streets [UBQQSG Report, 24/10-30/10/75], the UBQQSG reported at least two cases of Northern soldiers (bộ đội) being brutally murdered in District 3 and in the $\mathrm{Cu}$ Chi district [UBQQSG Report, November - 10/12/75]. Meanwhile, protests multiplied in November and December 1975 against reunification. They demanded the end of the Northern presence, denounced the displacement of Southerners and the re-settling of Northerners in the city, and claimed that "The South is for Southerners."

Table 3. Geographical origins and Party memberships of the cadres assigned to the agricultural affairs transition committee in Saigon - Gia Dinh

\begin{tabular}{|c|c|c|c|c|c|c|}
\hline & North & $\begin{array}{l}\text { North- } \\
\text { Central } \\
\end{array}$ & $\begin{array}{l}\text { South- } \\
\text { Central }\end{array}$ & South & Cambodia & Total \\
\hline Numbers & 15 & 5 & 3 & 44 & 3 & 70 \\
\hline Percentage & $21 \%$ & $7 \%$ & $4 \%$ & $63 \%$ & $4 \%$ & $100 \%$ \\
\hline Party Members & 7 & 4 & 3 & 30 & 2 & 46 \\
\hline Percentage & $47 \%$ & $80 \%$ & $100 \%$ & $68 \%$ & $67 \%$ & $66 \%$ \\
\hline $\begin{array}{l}\text { Youth group } \\
\text { (Đoàn) members }\end{array}$ & 3 & 1 & & & & 4 \\
\hline Percentage & $20 \%$ & $20 \%$ & & & & $6 \%$ \\
\hline Non-affiliated & 5 & & & 14 & 1 & 20 \\
\hline Percentage & $33 \%$ & & & $32 \%$ & $33 \%$ & $29 \%$ \\
\hline Average age & 30 & 34 & 43 & 41 & 30 & 38 \\
\hline $\begin{array}{l}\text { Average age of } \\
\text { Party members }\end{array}$ & 33 & 37 & 43 & 43 & 36 & 41 \\
\hline \multicolumn{7}{|c|}{$\begin{array}{l}\text { North is the area above Thanh hóa province; North-Central covers the area from Thanh hóa province to the } 17^{\text {th }} \text { parallel } \\
\text { South-Central zone from the } 17^{\text {th }} \text { parallel to the present provinces of Đắk Nông, Lâm Đồng and Bình Thuận; South i } \\
\text { the south area. }\end{array}$} \\
\hline
\end{tabular}

Source: Compiled from Cơ quan Nông nghiệp R - Danh sách cán bộ nhân viên của cơ quan nông nghiệp R được cử đi làm nhiệm vụ đột xuất - 23/04/75 - TM. Ban lãnh đạo cơ quan - Nguyễn Văn Tắt in HS 73: Tài liệu của Bộ Kinh tế Tài chính, Ủy ban Quân Quản TP. HCM về công tác tiếp quản năm 1975-1976 [Agriculture Agency R - List of officers and employees of agricultural agency R sent on unscheduled missions - 23 April 1975 - TM. Agency leadership - Nguyen Van Tat in HS: Documents of the Ministry of Economy and Finance, Ho Chi Minh City Military Administration Committee on the takeover in 1975-1976], TTLTQGII

The UBQQSG was keen on not letting the situation get out of hand and set its public security department to work on such unrest. As the following table shows, only in the last months of 1975, they cracked down upon dozens of military cases (seizing weapons and explosives, dismantling clandestine groups, and arresting former ARVN personnel that were evading reeducation and plotting to overthrow the new government), hundreds of political cases. They also went after criminals and 
delinquents who tried to take advantage of the underlying turmoil, with the new police forces directing special attention to the increase in thefts and burglaries (Table 4).

Trying to end a thirty-year civil war in a city that housed a significant population that had once dedicated a large part of their lives to actively fight against the revolution was no small matter. However, if the UBQQSG at the top level seem to have privileged some form of leniency in its approach to opposition, first-hand accounts from Saigon inhabitants report local revolutionary committees imposing a much harsher form of punishment and retaliation, seemingly out of the UBQQSG's control. This lead Saigonese revolutionary sympathizer Huynh Tran Đuc, faced the numerous excesses he witnessed to ask: "But where are we going if the central authorities are always overwhelmed by the revolutionary committees?” [Friang, Huynh Tran Đuc 1976].

Table 4. Resistance activities and infringements on public order in the last three months of 1975

\begin{tabular}{|c|c|c|c|}
\hline & October & November & December \\
\hline Enemy activities & 571 & 740 & 448 \\
\hline Military cases & 34 & 48 & 15 \\
\hline $\begin{array}{c}\text { Political cases (distributing flyers, } \\
\text { spreading rumors of fake news, flight } \\
\text { abroad) }\end{array}$ & 100 & 126 & 351 \\
\hline $\begin{array}{c}\text { Public order violations } \\
\text { Theft/Burglaries }\end{array}$ & 336 & 605 & 293 \\
\hline
\end{tabular}

Source: Compiled from the data of UBQQSG reports in HS.50: Báo cáo của Ủy ban Nhân dân Quân quản TP. Hồ Chí Minh về tình hình thành phố năm 1975 [Report of the People's Committee of Military Administration of Ho Chi Minh City. Ho Chi Minh City on the situation in 1975], Phông Ban Kinh tế Kế hoạch miền Nam (BKT Fonds), TTLTQGII

\section{Keeping control over the apparatus, the cadre discipline in question}

Indeed, the other major issue that the UBQQSG had to deal with was maintaining the discipline of revolutionary cadres throughout this period. Indeed, the «poison pills encased in sugar of the South» that the DRV Prime Minister Phan Van Đong cautioned against were not a baseless claim. Cases of cadres visiting prostitutes, abuses of power, bureaucratic overcomplications, and failures to comply with the ideological and moral standards of the revolution were repeatedly brought to the UBQQSG's attention. Yet UBQQSG reports contain no mentions of summary executions of thieves, delinquents or political opponents related in other sources [Friang, Huynh Tran Đuc 1976]. One particular kind of abuse was especially worrisome to the revolutionary authorities: the unlawful confiscation of property. As soon as on 1 May 1975, revolutionary agents had started to confiscate the properties of those who had left before 30 April as a way to obtain facilities for their new institutions ${ }^{1}$. These were relatively victimless expropriations at the time, since the owners had left with apparently no plans to return to the country. The confiscation of property was also one of the prescribed punishments for former RVN civil servants and those active enemies of the new revolutionary regime. But these confiscations seemed to have quickly gotten out of the revolutionary

\footnotetext{
${ }^{1}$ Interview with a former member of a Party intellectuals' cell (trí vận) who was assigned the task of finding an empty villa to host their organization.
} 
authorities' control. On 18 June, the COSVN circulated a directive reporting numerous abuses in the seizing of vehicles, electrical appliances, books, and housing all together [COSVN Documents, Vol. 18, 2020: 847]. These abuses were blamed on reactionary elements that had infiltrated the revolution's state apparatus, or on self-proclaimed transition cadres who used their weapons to force the people out of their homes. Both the COSVN and the UBQQSG intervened to stop these abusive confiscations by reaffirming who were the competent authorities to order seizures and under what conditions [UBQQSG Internal notice, 20/06/75]. That did not deter some of the abusive cadres. Some of them even allegedly falsified the signatures of UBQQSG's chief of security Cao Đang Chiem (Cao Đăng Chiếm) to provide themselves fake mandates to confiscate properties from urbans inhabitants [UBQQSG Notice, 19/07/75]. To the dismay of the revolutionary authorities, abusive seizures of property that forced people to live on the streets or in the markets were reported to the UBQQSG until December 1975. That month, the UBQQSG reported 156 complaints, with one case being the unlawful eviction of the agency for the water management of the city [UBQQSG Report, November 1975]. Finally, the UBQQSG decided to start a construction program for new houses in order to stop the confiscations [UBQQSG Report, December 1975].

The response that the UBQQSG adopted to deal with these discipline issues was two-fold. First, the organizational committees of the COSVN and the UBQQSG created training programs for cadres to reinforce their quality and their morals whilst performing their duties. The second solution, as COSVN called for as early as June 1975, was to implicate the masses into forcing the cadres to uphold revolutionary discipline, going as far as prescribing people's trials to condemn abusive cadres [COSVN Documents, Vol. 18, 2020: 848]. In practice, this translated into some self-criticism sessions that took place at the very local level where cadres would go in front of the masses and explain "the negative points of their behavior" [UBQQSG Report, 07/11 - 14/11/75]. These sessions were considered to be a crucial step in building the democracy that the revolutionary authorities wanted, but more importantly they forced the revolutionary agents to stay in touch with the people's living conditions and preoccupations, to remind the cadres that they were serving the people and not to create weak points that counter-revolutionaries could exploit to divide the nation. It is difficult to establish whether or not these measures were effective in bringing back the rank and file in line with the top.

\section{Conclusion: broadening perspectives and time frames on the final stage of the Vietnam War}

The return to the civilian administration was planned since the beginning of the takeover. On 30 July, the Revolutionary People's Committee of Ho Chi Minh City (Ủy ban nhân dân cách mạng thành phố Hồ Chi Minh, RPCHCMC) was created with 22 former members of the NLF/PRG. The COSVN called for the transfer to the civilian administration in the rest of the Republic of South Vietnam in August 1975 [Draft COSVN Resolution, June 1975], but the UBQQSG continued its mission until 20 January 1976. On that day, the PRG ended the UBQQSG's existence and officially entrusted its charge to the newly composed RPCHCMC lead by Vo Van Kiet, along with 15 other commissioners. A Southerner was still at the head of the city's state apparatus to look over the final preparation stages before the official reunification under the Socialist Republic of Vietnam on 2 July 1976, but Saigon's hardships were far from over.

After 30 April 1975, the Southern liberation movement and the revolutionary discourse that it carried faced the enormous challenge of taking over a dire situation in Saigon and treating the open wounds created by thirty years of civil war. The UBQQSG was, in the eyes of Vietnamese revolutionaries, the necessary step to stabilize the situation before beginning the process of reunifying 
the country. The UBQQSG was, to some extent, the embodiment of the Southern indigenous liberation movement and managed to implement some of the revolutionary policies in the city. However, it fell short on a number of considerable issues like ensuring security and order within the city or keeping the state apparatus and the local under a strict discipline. Even though it seems clear that the non-communist leadership of the NLF and the PRG was marginalized, it is also worth noting that the Republic of South Vietnam was still the official regime south of the 17th parallel until the proclamation of the Socialist Republic of Vietnam (SRVN). While this might only point to a regime that only existed on paper, archival documents show that Southern cadres and Party members played a very important role in the state apparatus for transition. They also reveal that the newly established revolutionary administration did not aim at punishing the South but was rather trying to establish itself in the minds of its compatriots as the legitimate power that had the people's best interest at heart. Despite the fact that the fighting had been minimal after the last days of April 1975, the major questions raised during the war, at the center which was the future of the Southern revolution itself, were still the dominant currents which directed the final stages of the Vietnamese revolution.

It is the opinion of the author that a revision of the dates in which we often bracket the war would be more than beneficial to our understanding of the political dynamics of modern Vietnam. Pushing back the final date of the war period to 1976 and the proclamation of the SRVN would indeed allow researchers to take into account the prolonged existence of the separate South Vietnamese state that the UBQQSG embodied, at least nominally. An entity that contained in itself an idea of the revolution, still within the framework of the Communist Party, but that may have differed slightly from Hanoi's agenda. The fourteen-month period from 30 April 1975 until 2 July 1976 could therefore be understood not only as a period of increasing "Northernization" of the South, but also as the moment when the strengths and the convictions of the South Vietnamese revolutionaries, broadcasted through decades of pro-liberation propaganda, would be put to the test of overseeing a transition in war-ravaged territory under US embargo after thirty years of civil strife.

\section{References}

\section{Vietnam's National Archives Center no.2}

Phông Ban Kinh tế Kế hoạch miền Nam (Committee for the Economy and Planification of the South) (BKT Fonds):

Folder 50. Reports of the UBQQSG on the situation of the city in 1975: 30/04/75 - 20/07/75, 31/504/06/75 -07/06/75, 04/08 - 07/08/75, 10/10 - 17/10/75, 24/10 - 30/10/75, 07/11 - 14/11/75, 14/11 20/11/75, November - 10/12/75, December 1975;

Folder 167. Documents of the UBQQSG on the policies for ensuring the security, the economy and maintaining order in the society in 1975:

- Report 31/5 - 04/06/75,

- Internal notice on the arrests and property confiscations 20/06/75,

- Notice 19/07/75.

Văn phòng Ban Chấp hành Trung ương (2020). Văn kiện Trung uoong Cục miền Nam Giai đoạn 19461975 [Cabinet of the Executive Committee. COSVN Documents 1946-1975]. T. 18 (1974-1975). Hà Nội: Nxb Chính trị Quốc gia Sự thật:

- COSVN Directive 06/CT.75;

- COSVN Directive 08/CT.75;

- COSVN Circular 12/TT.75;

- Draft COSVN Resolution, June 1975.

Asselin P. (2018). Vietnam's American War: A History. Cambridge: Cambridge University Press. 
Elliot D. (2016). The Vietnamese War: Revolution and Social Change in the Mekong Delta, 19301975. Taylor and Francis.

Friang B., Huynh Tran Duc (1976). La mousson de la liberté: Vietnam, du colonialisme au stalinisme [Monsoon of Freedom: Vietnam, from Colonialism to Stalinism]. Paris: Plon.

Goscha C. (2016). The Penguin History of Modern Vietnam. London: Penguin Books.

Goscha C., Larcher A. (2011). Vietnam: un État né de la guerre 1945-1954 [Vietnam: A State Born from the 1945-1954 War]. Paris: Armand Colin.

Guillemot F. (2018). Viêt-Nam, fractures d'une nation: Une histoire contemporaine de 1858 à nos jours [Vietnam, Fractures of a Nation: A Contemporary History from 1858 to the Present]. Paris: La Découverte.

Hà Minh Hồng (chủ biên) (2019). Chính phủ cách mạng lâm thời Cộng hòa miền Nam Việt Nam: 1969-1976 [Provisional Revolutionary Government of the Republic of South Vietnam: 1969-1976]. TP. Hồ Chí Minh: Nxb Đại học Quốc gia TP. Hồ Chí Minh,

Hồ Sơn Đài (2015). Những ngày đầu tiếp quản [The first days of takeover]. Báo Sài Gòn Giải phóng, April, 27.

Huy Đức (2012). Bên thắng cuộc. I. “Giải phóng” [Winning side. I. “Liberation”']. Los Angeles, California: OsinBook.

Lacouture J., Lacouture S. (1976). Vietnam, voyage à travers une victoire [Vietnam, Journey through Victory]. Paris: Éditions du Seuil.

Lien-Hang Nguyen (2012). Hanoi's war: an international history of the war for peace in Vietnam. Chapel Hill: University of North Carolina Press.

Nguyễn Đình Thống (chủ biên) (2019). Chính phủ cách mạng lâm thời Cộng hòa miền Nam Việt Nam: 1969-1976 [Provisional Revolutionary Government of the Republic of South Vietnam: 1969-1976]. TP. Hồ Chí Minh: Nxb Tổng hợp TP. Hồ Chí Minh.

Trương Như Tảng (1986). A Vietcong memoir [In Vietcong Memoir]. New York: Vintage Books.

\section{Author:}

Lê Antoine, $\mathrm{PhD}$ Candidat, National Institute for Eastern Languages and Civilization (INALCO), Center for Southeast Asian Studies (CASE). E-mail: antoine-le@ @otmail.com

Article history:

Received: 13 September 2021

Received in revised form: 6 November 2021

Accepted: 22 December 2021 